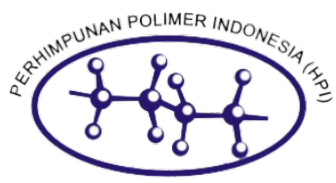

\title{
Modified of Cellulose Acetate/Polyethylene Glycol Membrane by the Addition of Graphene Oxide
}

Siti Nurkhamidaha ${ }^{ }$, Arnesya Ramadhani ${ }^{\mathrm{a}}$, Bertiningrum Cintya Devi ${ }^{\mathrm{a}}$, Bagus Arief Febriansyah ${ }^{\mathrm{a}}$, Retno Dwi Nyamiatia, Yeni Rahmawati

\begin{abstract}
Cellulose acetate (CA) has been known as a polymeric membrane for desalination membrane. Many studies have been attempted to increase its performance. In this study, CA has been blended with polyethylene glycol (PEG) with graphene oxide (GO) was then added into the blended CA-PEG as many as $0,0.0025,0.0050,0.0075,0.0100,0.0125 \mathrm{wt} . \%$ based on solvent. The hydrophilicity of membranes was analyzed by using Fourier Transformed Infra-Red (FTIR), whereas its morphology was analyzed using Scanning Electron Microscope (SEM). The mechanical property was analyzed by Dynamic Mechanical Analysis (DMA). Membrane's performances were analyzed from their salt rejection, permeate flux, and permeability. The analysis in the area of $-\mathrm{OH}$ functional group from FTIR results and water content shows that hydrophilicity of membrane increases with the addition of GO. The morphology of membranes shows a finger-like, and sponge-like structure with the smallest pore size is 0.02 micron, which was achieved from the addition of $\mathrm{GO}$ of 0.0050 wt.\%. Salt rejection of membrane increases with the addition of $\mathrm{GO}$ up to $0.0050 \mathrm{wt} . \%$ and further decreased with the increase of GO. The optimal membrane performance was achieved by the addition of $\mathrm{GO} 0.0050 \%$ with the salt rejection of $82 \%$, permeate flux $626.743 \mathrm{~L} / \mathrm{m}^{2} \mathrm{~h}$, and membrane also exhibits the mechanical property of $180.2 \mathrm{kPa}$.
\end{abstract}

Selulosa asetat (CA) telah dikenal sebagai membran polimer untuk membran desalinasi. Banyak penelitian telah dilakukan untuk meningkatkan kinerja membran tersebut. Dalam penelitian ini, CA telah dicampur dengan polietilen glikol (PEG) dengan graphene oxide (GO) kemudian ditambahkan ke dalam campuran CA-PEG sebanyak 0; 0,0025; 0,0050; 0,0075; 0,0075; 0,0100; 0,0125 wt.\%. Hidrofilisitas membran dianalisis dengan menggunakan Fourier Transformed Infra-Red (FTIR), sedangkan morfologinya dianalisis menggunakan Scanning Electron Microscope (SEM). Properti mekanik dianalisis oleh Dynamic Mechanical Analysis (DMA). Kinerja membran dianalisis dari salt rejection, permeate flux, dan permeabilitas. Analisis di bidang gugus fungsi $-\mathrm{OH}$ dari hasil FTIR dan kadar air menunjukkan bahwa hidrofilisitas membran meningkat dengan penambahan GO. Morfologi membran menunjukkan struktur seperti jari, dan seperti spons dengan ukuran pori terkecil adalah 0,02 mikron, yang dicapai dari penambahan $\mathrm{GO}$ sebesar $0,0050 \%$ berat. Salt rejection terhadap membran meningkat dengan penambahan GO hingga $0,0050 \%$ berat dan semakin menurun dengan meningkatnya GO. Kinerja membran optimal dicapai dengan penambahan GO 0,0050\% dengan salt rejection $82 \%$, permeate flux $626,743 \mathrm{~L} / \mathrm{m}^{2} \mathrm{~h}$, dan membran juga menunjukkan sifat mekanis sebesar 180,2 $\mathrm{kPa}$.

1 October 2019

Received in revised form

26 December 2019

Accepted

28 December 2019

Published

31 December 2019

Keywords: Cellulose acetate, desalination, grafting, graphene oxide, membrane.

\section{Introduction}

Cellulose acetate (CA is a well-known membrane for the desalination process since it potential to produce high flux, low cost, and good hydrophilicity. ${ }^{1}$ However, the CA membranes undergo poor chemical resistance, ${ }^{2}$ bad thermal stability, and low antifouling properties, thus resulting in the short life of membranes and decreasing of membrane performance such as permeability and rejection. ${ }^{3,4}$

In order to improve its performance, CA was blended with nanoparticle to decrease pore size as well as to increase membrane performance. ${ }^{5,6}$ Titanium dioxide $\left(\mathrm{TiO}_{2}\right)$ was also added to polymer the increase of water flux due to the enhanced hydrophilicity in the

a. Chemical Engineering Department, Faculty of Industrial Technology, Institut Teknologi Sepuluh Nopember (ITS), Kampus ITS Sukolilo, Surabaya 60111 Indonesia † Corresponding author: nurkhamidah@chem-eng.its.ac.id. membranes. When the concentration of $\mathrm{TiO}_{2}$ was $5.0 \mathrm{wt} . \%$, the optimum membrane performance was obtained together with strong mechanical properties. ${ }^{7-10}$ The experiment results show that hydrophilicity of the CA/PEG membrane increases with the addition and the increase of CNT contents. Flux permeates, and permeability of membrane increases with the increasing of CNT levels, and silicon dioxide $\left(\mathrm{SiO}_{2}\right)$ endows the membranes with high comprehensive properties including surface hydrophilicity, pure water flux, anti-compression property and mechanical strength. ${ }^{11}$

To the best of our knowledge, blending PEG with CA has not been evaluated yet. This study aimed to blend CA with polyethylene glycol (PEG) to improve its property on salt rejection and flux permeation. PEG was used since its hydrophilic material. Furthermore, to increase salt rejection, graphene oxide (GO) was added to the $\mathrm{CA} / \mathrm{PEG}$ membrane via the grafting method. Membrane properties and their performance were evaluated in this study. 


\section{Experimental Methods}

Materials

Cellulose acetate (CA, 30,000 Da, with acetyl content 39.8\%) and polyethylene glycol-400 (PEG, $400 \mathrm{Da}$ ) were purchased from Sigma Aldrich. Graphene oxide (GO) with a bulk density of $1.8 \mathrm{~g} \mathrm{~cm}^{-3}$, was purchased from Sigma Aldrich. Acetone and dimethylformamide (DMF) were used as solvent and water as nonsolvent. $\mathrm{NaOH}$ was purchased from Sigma Aldrich. $\mathrm{ClCH}_{2} \mathrm{COONa}$ was purchased from Sigma Aldrich. $\mathrm{HCl}$ was purchased from Sigma Aldrich.

\section{Method}

\section{Grafting Method}

An amount of $3.75 \mathrm{~g}$ of $\mathrm{NaOH}$ and $3.75 \mathrm{~g}$ of $\mathrm{ClCH}_{2} \mathrm{COONa}$ were dissolved in a $300 \mathrm{~mL} \mathrm{GO}$ suspension $\left(1 \mathrm{mg} \mathrm{mL}^{-1}\right)$, then sonicated for 2.5 hours, followed by neutralization with $0.1 \mathrm{M} \mathrm{HCl}$. The resulting $\mathrm{GO}(\mathrm{GO}-\mathrm{COOH})$ suspension was purified by repeated rinsing and centrifugation ( $15,000 \mathrm{rpm}$ for $7 \mathrm{~min}$ ) then heated at $100^{\circ} \mathrm{C}$. PEG of $1.5 \mathrm{~g}$ dissolved in $30 \mathrm{~mL}$ dichloromethane, add $0.06 \mathrm{~g}$ of dimethylaminopyridine, and GO-COOH dissolved in $20 \mathrm{~mL}$ of DMF then stirred for 5 minutes $0.5 \mathrm{~g}$ DCC is dissolved in $5 \mathrm{~mL}$ of dichloromethane and added to the $\mathrm{GO}-\mathrm{COOH}$ solution after that stirred for 24 hours at mild temperatures. Repeated rinsing then heated to $100{ }^{\circ} \mathrm{C}$, produced GO Grafting. ${ }^{12}$

\section{Membrane CA/PEG/GO}

Preparation of the CA/PEG polymer membrane with ratio $80 / 20$ was prepared by mixing $2 \mathrm{~g}$ of CA and $0.5 \mathrm{~g}$ of PEG in $17 \mathrm{~mL}$ acetone/DMF 50/50. GO grafting was added by dissolving GO in a CA/PEG membrane solution with $\mathrm{GO}$ variable composition 0 , $0.0025,0.0050,0.0075,0.0100$, and $0.0125 \mathrm{wt} . \%$ of the solvent and it was named as CGG 0, CGG 1, CGG 2, CGG 3, CGG 4, and CGG 5, respectively. The solution was then mixed using a hotplate at $70{ }^{\circ} \mathrm{C}$ for 12 hours to cast and immersed in water to produce a flat sheet membrane.

\section{Membrane Characterization}

CA/PEG/GO membrane characterization was observed by its hydrophilicity, by Fourier Transformed Infra-Red (FTIR), the membrane is inserted into the FTIR device and analyzed, then reading graphs formed to observe $\mathrm{OH}$ group, while its morphology was observed by using Scanning Electron Microscopy (SEM), the membrane is dipped in liquid nitrogen during a few seconds later it was broken and then the membrane is coated in advance with AuPd. Samples are then analyzed by SEM instrument.

\section{Membrane Performance}

Salt rejection is the efficiency of membrane and its ability to remove contaminates, and calculated by using the equation below:

$R=\frac{1-C_{p}}{C_{f}} \times 100 \%$

where $R$ is the percentage of salt rejection, $C_{p}$ (in ppm) is the salt concentration in permeate, $C_{f}$ (in ppm) is the salt concentration in the feed water. The permeate flux $(J)$ represents the amount of pure water collected per unit time and per unit area at variable pressures. It was calculated by equation below:

$J=\frac{Q}{t} \times A$
Where $J$ is the permeate flux $\left(\mathrm{mL} / \mathrm{m}^{2} \mathrm{~h}\right), Q$ is the amount of permeate $(\mathrm{mL}), t$ is the time, and $A$ is the area $\left(\mathrm{m}^{2}\right)$.

\section{Result and Discussion}

\section{Fourier Transformed Infra-Red (FTIR)}

Fourier Transformed Infra-Red Spectroscopy (FTIR) is a method of analysing chemical compounds using infrared light. FTIR analysis results for CA/PEG membranes with the addition of GO using the grafting method can be seen in Figure 1. The $-\mathrm{OH}$ group is indicated by a peak at the wavelength $3000-3700 \mathrm{~cm}^{-1}, \mathrm{C}-0$ group at $1100 \mathrm{~cm}^{-1}$, $\mathrm{C}-\mathrm{O}-\mathrm{C}$ group at $1240 \mathrm{~cm}^{-1}$, and C $=0$ group at $1600-1800 \mathrm{~cm}^{-1}$. Membrane hydrophilicity can be seen from FTIR analysis that was shown by the presence of hydroxyl groups. The peak area of $-\mathrm{OH}$ group calculations is presented in Table 1. CGG1 has a similar $-\mathrm{OH}$ area with membrane CGGO. However, the higher the GO content, the higher the peak area of $-\mathrm{OH}$ group. Based on the peak area of the FTIR, it shows that the addition of GO increased the hydrophilicity of the CA/PEG membrane because the addition of $\mathrm{GO}$ will increase $-\mathrm{OH}$ groups and $\mathrm{C}-\mathrm{O}-\mathrm{C}$ groups so that the resulting peak area is getting wider.

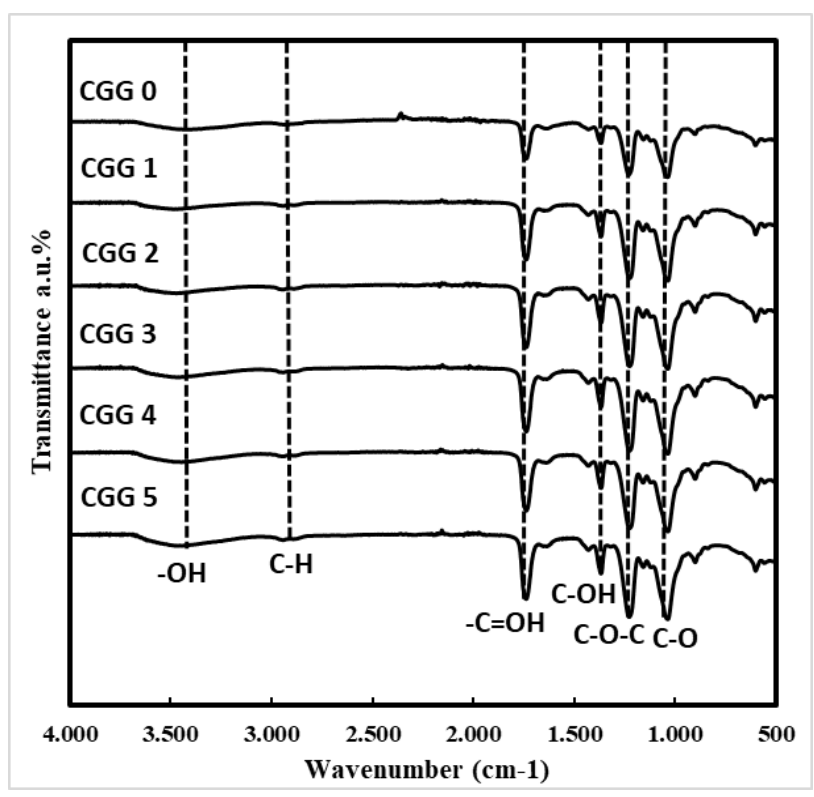

Figure 1. FTIR spectra of CA/PEG/GO membrane.

Table 1. Peak $-\mathrm{OH}$ area on the FTIR spectra CA/PEG/GO membrane

\begin{tabular}{ccc}
\hline Membrane & Peak Area (area unit) & Deviation (\%) \\
\hline CGG 0 & 1.87 & \\
CGG 1 & 1.86 & -1 \\
CGG 2 & 1.88 & 1 \\
CGG 3 & 1.89 & 1 \\
CGG 4 & 2.25 & 20 \\
CGG 5 & 2.48 & 33 \\
\hline
\end{tabular}

From the SEM micrographs in Figure 2, the morphological structure of the membrane in the fractured surface can be observed. 
Pore size variations due to the addition of GOs affected membrane porosity resulting in the increasing of finger-like pore size and the reduction of wall thickness, which increased membrane permeability. Increased porosity is also caused by GO's hydrophilic nature, provides wider pores. ${ }^{14}$ The addition of GO the CA/PEG membrane increased the viscosity of the membrane, caused a slower de-mixing process, which is further changed to membrane porosity.

Scanning Electron Microscopy Characterization (SEM)
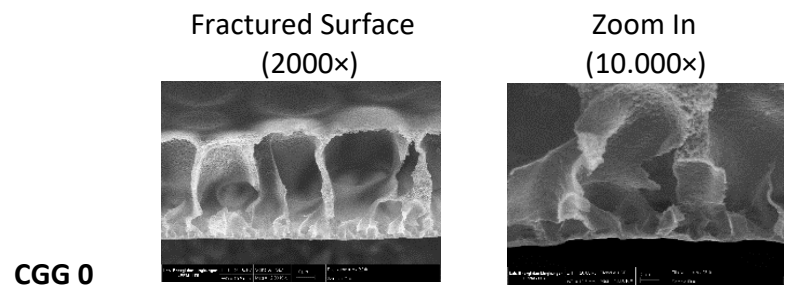

CGG 1
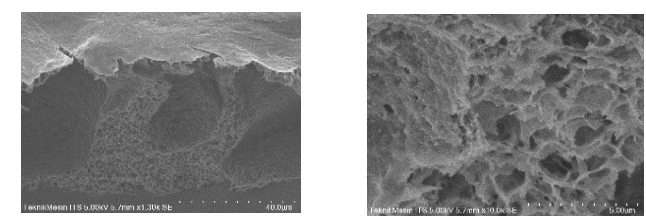

CGG 2

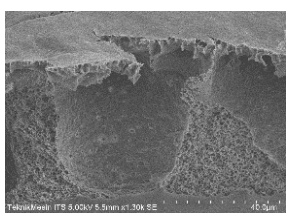

CGG 3

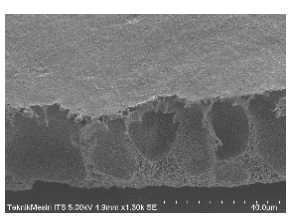

CGG 4
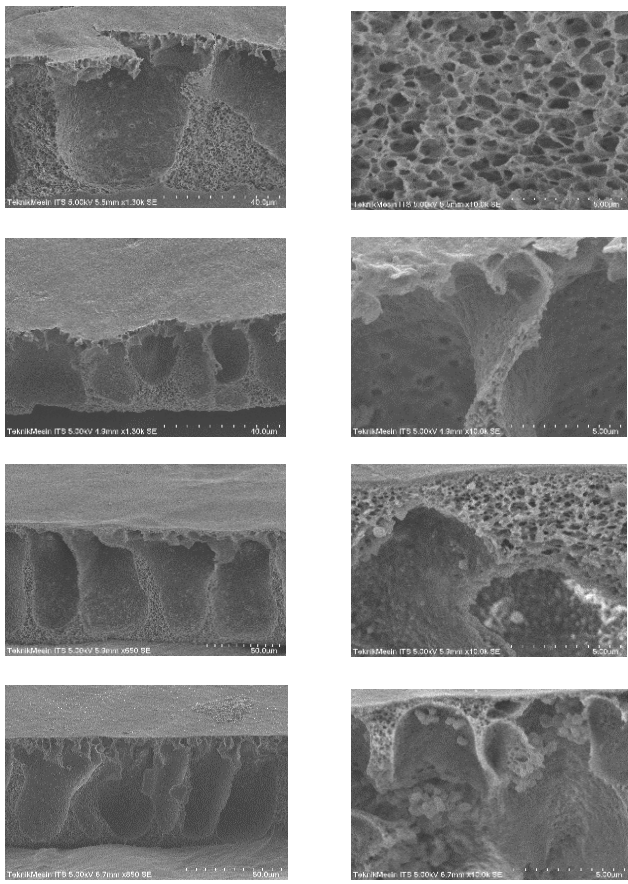

CGG 5

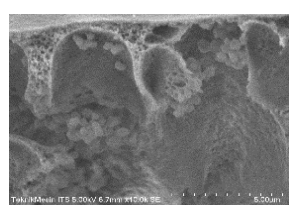

Figure 2. SEM micrographs of CA/PEG/GO membranes.

\section{Salt rejection, Flux Permeate, and Permeability}

\section{Salt rejection and Flux Permeate}

Salt rejection and flux permeate on the CA/PEG/GO membranes by grafting method can be seen in Figure 3. Salt rejection of the CA/PEG membrane increased with the addition of GO. The highest salt rejection, 82\%, achieved from the CGG 2 membrane. An increase in salt rejection was due to the addition of $\mathrm{GO}$ and further increased its sponge-like pore volume. ${ }^{12}$ However, optimal for the addition of GO is $0.005 \%$ wt, more than that such as CGG 3, CGG 4, and CGG 5 membrane hydrophilicity will be higher and decreased salt rejection.

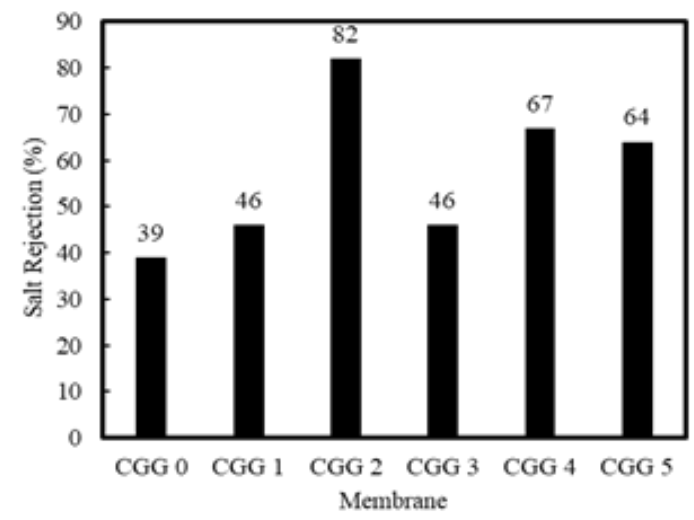

(a)

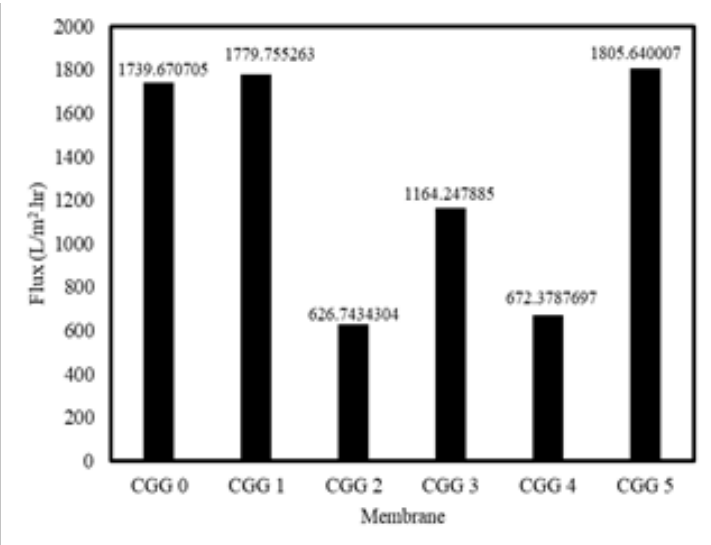

(b)

Figure 3. (a) Salt rejection and (b) flux CA/PEG/GO membranes.

Permeate flux of CGG 2 is low. This is due to the small pore size. A similar high permeate flux occurred in CGG 3 and CCG 4 . However, the permeate flux of CGG 5 is high. This result is in agreement with FTIR analysis. CGG 5 has a wider $-\mathrm{OH}$ area indicating this membrane is hydrophilic. The highest flux value is CGG 5, with the highest GO content of $0.0125 w t \%$. CGG 0 and CGG 1 also have high flux values. This is because the pore sizes of CGG 0 and CGG 1 are quite large. A Large pore is an effect of adding CA/PEG because it has the potential to produce high flux and good hydrophilicity. ${ }^{1}$

\section{Permeability}

The results of the CA/PEG membrane permeability by grafting method showed a tendency to decrease the permeability of this membrane. The lowest permeability value is CGG 4 with the addition of GO $0.010 w t \%$ of the polymer, and the highest permeability value is CGG 1 of $0.001648 \mathrm{~L} / \mathrm{m}^{2} \mathrm{~h} \mathrm{kPa}$ with GO content of 0.0025 $w t \%$. The decrease in permeability is thought to occur due to the clumping of layers from GO which causes the path through which water molecules in the membrane become longer and winding, ${ }^{13}$ so the addition of GO will reduce the permeability value of the membrane. 


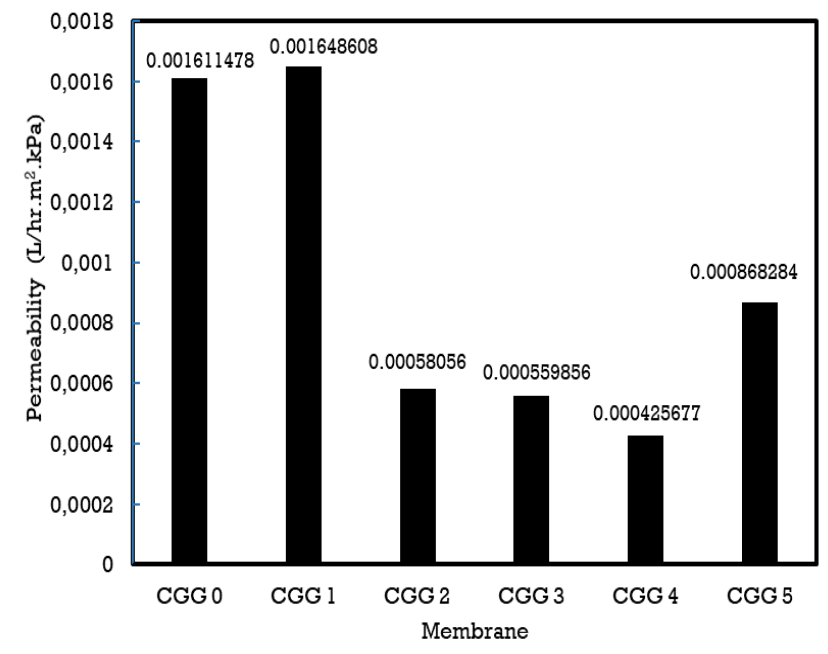

Figure 4. Permeability $\mathrm{CA} / \mathrm{PEG} / \mathrm{GO}$ membrane with grafting method.

\section{Dynamic Mechanical Analysis (DMA)}

DMA analysis used to measure the mechanical and viscoelastic properties of the membrane. Figure 4 shows the mechanical property of CA/PEG/GO membranes. The membranes with GO addition of 0.0025 and $0.0050 \mathrm{wt} \%$ of the solvent are able to handle more tensile stresses before permanent deformation occurs. It can be assumed that a small concentration of GO increases the pressure on the membrane. However, a higher concentration had an adverse effect on the membrane, thus caused it to fail under less stress. ${ }^{14}$

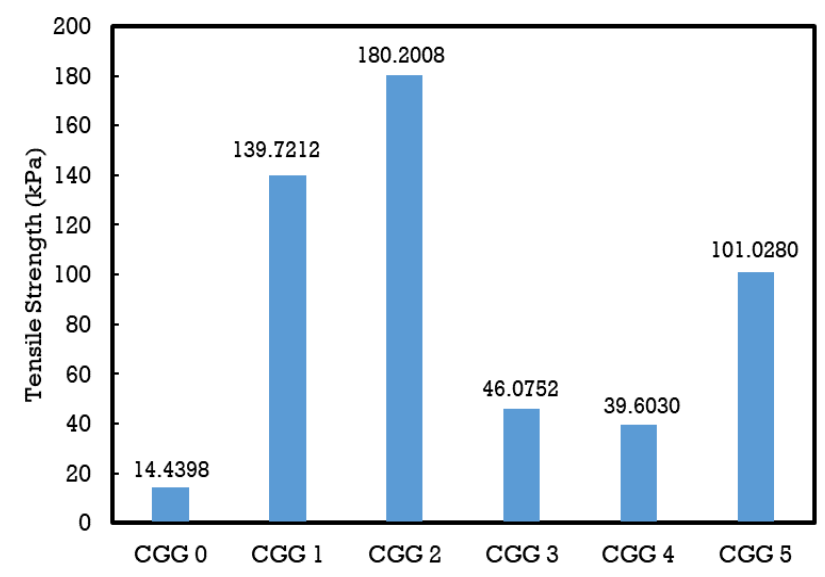

Figure 5. Tensile strength results of CA/PEG/GO membranes.

\section{Conclusions}

The addition of GO by grafting method has an effect on the increase of hydrophilicity of CA/PEG membranes. The highest hy-drophilicity value was on CGG 5 with the addition of $0.0125 \% \mathrm{GO}$, indicated by the high area value of the $-\mathrm{OH}$ group, which is 2.48 (area unit). In our experiment, the optimal GO addition was CGG 2, which was marked by the highest value of salt rejection. CGG 2 with addition of $0.005 \%$ GO show highest salt rejection $82 \%$, permeate flux of $626.743 \mathrm{~L} / \mathrm{m}^{2} \mathrm{~h}$, and permeability of $0.00058 \mathrm{~L} / \mathrm{m}^{2} \mathrm{~h} \mathrm{kPa} \mathrm{CGG} \mathrm{2,} \mathrm{as} \mathrm{well} \mathrm{as} \mathrm{ex-}$ hibits the best mechanical property.

\section{Conflicts of Interest}

There are no conflicts to declare.

\section{Acknowledgments}

This research has been funded by the Ministry of Research Technology and Higher Education, Republic of Indonesia, with a contract number of 6/E/KPT/2019 and 188/PKS/ITS/2019.

\section{References}

1 Y. Shi, C. Li, D. He, L. Shen and N. Bao, Preparation of graphene oxide-cellulose acetatenanocomposite membrane for high-flux desalination, J. Mater. Sci., 2017, 52(22), 13296-13306.

2 H. El-Saied, A. H. Basta, B. N. Barsoum and M. M. Elberry, Cellulose membranes for reverse osmosis cellulose acetate membranes including a composite with polypropylene. Desalination, 2003, 159(2), 171-181.

3 A. Ahmad, S. Waheed, S. M. Khan, S. e-Gul, M. Shafiq, M. Farooq, K. Sanaullah and T. Jamila, Effect of silica on the properties of cellulose acetate/polyethyleneglycol membranes for reverse osmosis, Desalination, 2015, 355, 1-10.

4 P. Rustemeyer, Acetate manufacturing, process and technology. History of CA and evolution of the markets, Macromol. Symp., 2004, 208, 1-6.

5 W. Y. Chuang, T. H. Young, W. Y. Chiu and C. Y. Lin, The effect of polymeric additives on the structure and permeability of poly(vinyl alcohol) asymmetric membrane, Polymer, 2000, 41, 5633-5641.

6 Y. Kim, Y. Noh, E. J. Lim, S. Lee, S. M. Choi and W. B. Kim, Starshaped Pd@Pt core-shell catalysts supported on reduced graphene oxide with superior electrocatalytic performance, J. Mater. Chem. A, 2014, 2(19), 6976-6986.

7 H. S. Lee, S. J. Im, J. H. Kim, H. J. Kim, J. P. Kim, B. R. Min, Polyamide thin-film nanofiltration membranes containing $\mathrm{TiO}_{2}$ particles, Desalination, 2008, 219, 48-56.

8 S. Nurkhamidah, Y. Rahmawati, I. Gunardi, P. Alifiyanti, K. D. Priambodo, R. L. Zaim and W. E. Muqni, Enhancing Properties and Performance of Cellulose Acetate/Polyethylene Glycol (CA/PEG) Membrane with the addition of Titanium Dioxide (TiO2) by Using Surface Coating Method, MATEC Web of Conferences, 2018, 156, 08016.

9 C. P. Leo, N. H. A. Kamil, M. U. M. Junaidi, S. N. M. Kamal and A. L. Ahmad, The potential of SAPO-44 zeolite filler in fouling mitigation of polysulfone ultrafiltration membrane, Sep. Purif. Technol., 2013, 103, 84-91.

10 S. Nurkhamidah, Y. Rahmawati, R. A. Gumilang, M. I. Riswanda, Y. E. Fahrizal and I. H. Ramadhan, AIP Conf. Proc., 2019, 2065, 030031. 
$11 \mathrm{H}$. Wu, J. Mansouri and V. Chen, Silica nanoparticles as carriers of antifouling ligands for PVDF ultrafiltration membranes. J. Membr. Sci., 2013, 433, 135-151.

12 CY. Wang, W. Wang, GL. Li, W. Li, WH. Tian and X. G. Li, The Influence of Interaction between Polyethylene Glycol and Graphene Oxide in Shape-stabilized PCMs on Their Phase Change Behaviours, Advance Materials Research, 2013, 800, 459-463.
13 M. Ioniță, L. E. Crica, S. I. Voic, S. Dinescu, F. Miculescu, M. Costache and H. lovu, Carbohydr. Polym., 2018, 183, 50-61.

14 H. Ravishankar, C. Jens, J. Veeriah, Graphene Oxide (GO)Blended Polysulfone (PSf) Ultrafiltration Membranes for Lead Ion Rejection, Membranes, 2018, 8(3), 77. 